Article Type: Research Paper

\title{
Determinants of Regional Economic Growth in Indonesia
}

Imamudin Yuliadi

\begin{abstract}
The research aims to analyze the effect of exchange rate, length of road, Human Development Index, regional expenditure, domestic investment, foreign investment, and total population on Gross Regional Domestic Product. The analysis used panel data estimation. Data were collected from Bank Indonesia and Statistics Indonesia (BPS) from 2010 to 2016. This research employed econometrics analysis in order to obtain the estimation result of the regional economic model in Indonesia that matched with statistics and economics theory criteria. After a series of econometric tests, the results showed that foreign investment, domestic investment, regional expenditure, exchange rate, Human Development Index, and length of road had a positive and significant effect on Regional Gross Domestic Product. Meanwhile, the total population had an insignificant effect on Regional Gross Domestic Product in Indonesia.

Keywords: Regional Economics; Regional expenditure; Regional investment; Human Development Index.
\end{abstract}

\section{CITATION:}

Yuliadi, I. (2020). Determinants of Regional Economic Growth in Indonesia. Jurnal Ekonomi \& Studi Pembangunan, 21(1), 125-136.

\section{ARTICLE HISTORY}

\section{Received:}

7 November 2019

Reviewed:

14 April 2020

Revised:

18 March 2020

Accepted:

19 April 2020

\section{Introduction}

Regional economic development in Indonesia has been dynamic since the post-independence era. The process of regional economic development is determined by several factors, such as regional economic potential, total population, infrastructure, the quality of human resources, and other macroeconomic variables, such as inflation level and exchange rate. In general, there is regional economic disparity caused by differences in endowment factors. It is because the supporting factors of economic growth in the western parts of Indonesia are relatively more advanced than in the eastern parts of Indonesia. In the regional scope, it is necessary to handle particular, sectoral, and regional economic gaps in a structured and comprehensive integrated way. The regional economic development indicated by Regional Gross Domestic Product is determined by economic activity and the regional potential that encompasses natural and human resources supported by the availability of infrastructure and regulation aspects (Zhang, 2017). The data of Indonesian annual macroeconomic indicator development is shown in the table as follows.

The research aims to investigate the determinants of Growth of Regional Gross Domestic Product in Indonesia that consists of many provinces and districts. Factors that might determine the Regional Gross Domestic 
Yuliadi

Determinants of Regional Economic Growth in Indonesia

Table 1 Indonesian Macroeconomic Indicators

\begin{tabular}{|c|c|c|c|}
\hline \multirow[t]{2}{*}{ Economic Indicators } & \multicolumn{3}{|c|}{ Year } \\
\hline & 2016 & 2017 & 2018 \\
\hline Growth of Gross Domestic Product (\%) & 5 & 5,1 & 5,3 \\
\hline Inflation (\% per year) & 3 & 3,5 & 3,5 \\
\hline Government Debt (\% from PDB) & 28,3 & 28,7 & 29,8 \\
\hline Currency Rate (IDR/USD) & 13.309 & 13.400 & 14710 \\
\hline Current Account (\% PDB) & $-1,8$ & $-1,6$ & $-1,8$ \\
\hline Total Population (in million) & 261 & 264 & 267 \\
\hline Poverty (\% population) & 10,9 & 10,1 & 9,8 \\
\hline Foreign Exchange Reserves (billion USD) & 116,4 & 130,2 & 120,7 \\
\hline Unemployment (\% of workforce) & 5,6 & 5,33 & - \\
\hline
\end{tabular}

Source: Bank Indonesia and Statistics Indonesia

Product in the research are such as length of the road, domestic investment, foreign investment, total population, exchange rate, regional expenditure, and Human Development Index (HDI). These variables are mentioned as determinant by previous research to examine the determinants of Regional Gross Domestic Product in Indonesia. The figure 1 is the Production possibility Frontier Curve to capture a process of increasing the production of goods and services.

Economic development is a process of increasing the production of goods and services, as indicated by PDRB growth. It is a process that involves economic and non-economic aspects. Economic development is also indicated by the increase of bureaucratic awareness, law awareness, and social ethics. (Todaro, 2000). Countries or regions, which experience development, are marked with a bureaucratic system and process that prioritize professionalism, transparency, accountability, responsibility, and quality of services. Regions that rely on primary sectors still depend on limited and non-renewable resources. The change of economic structure to the secondary and tertiary sectors indicates the increase of economic quality and quantity in fulfilling human needs (Wilson, 2017).

Theoretically, economic development requires economic growth marked by the increase in per capita income from year to year. Per capita income is determined by the amount of national income divided by the total population. The higher the national income, the higher the per capita income will be, assuming that the total population remains the same. The illustration of the economic growth process is marked by the shift of production possibility frontier to the right. Economic growth can occur because of the increase of factor endowment or technological progress so that the economic capacity and capability increase in terms of goods and services production (Diallo, 2018). The illustration of economic development is as follows figure 1.

The shift of Product Possibilities Frontier (PPF) curve indicates the economic development process caused by the increase of the production factor, including the amount of workforce, land, and capital. Economic development can also be caused by technological progress, which increases the capacity and quality of the production process (Epaphra, 2018). 


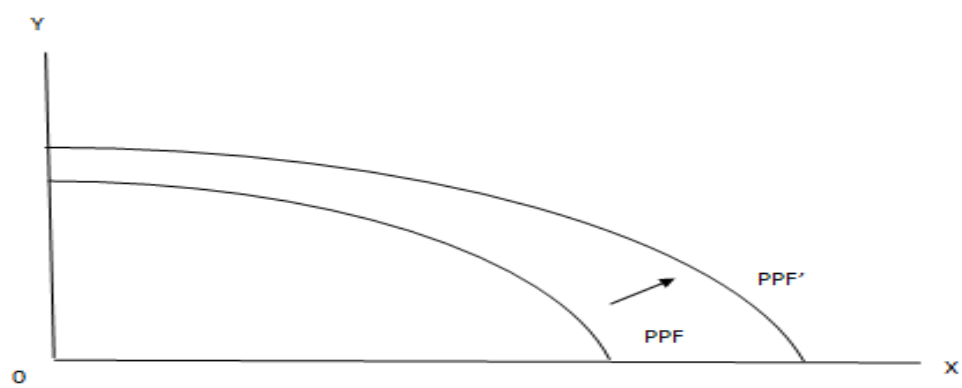

Figure 1 Production Possibility Frontier Curve Source: Todaro, Development Economic, 2000

The process of economic development is not merely an increase in goods and services production nor the increase of per capita income in an economy. It is also marked by the change of quality and intensity of institutional development and Human Resources. Regional economic development is also marked by the increase of public service quality by the apparatus in boosting the regional economy to a wealthier life (Pimentel, Harper, \& Martin, 2016).

The investment of production capacity will also increase, and there will be an increase in the stock of raw materials for the continuation of the production process. Through investment, innovation, and technology, it can also be developed so that the quality of production can boost economic development. Investment is also essential for economic development through human capital investment, which is made through education and training. The illustration of macroeconomic component changes and its effects on the economy is as follows figure 2 .

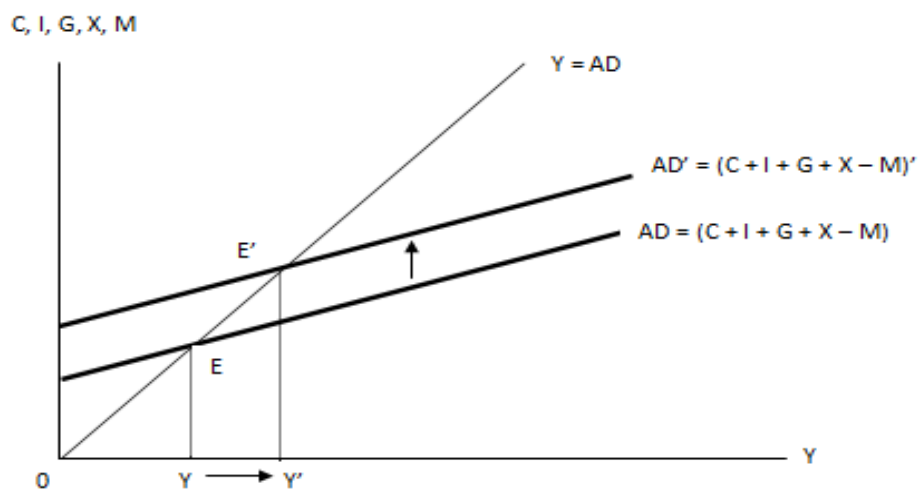

Figure 2 Keynesian Model and Macroeconomics Equilibrium Source: Dornbusch, Fischer, and Startz, 1998

The efforts to encourage domestic and foreign investors to invest are not easy things to do since they are related to people's choice and trust. However, the main aspect to increase investment is to build trust and optimism among the investors about the future of investments in regions. The concept of national income is formulated as follows:

$$
Y=C+I+G+(X-M)
$$


Disposable income $(\mathrm{Yd})$ is formulated into

$$
\begin{aligned}
& Y d=Y-T x+T r \\
& Y d=C+S
\end{aligned}
$$

Meanwhile, the allocation of disposable income $(\mathrm{Yd})$ are for consumption $(\mathrm{C})$ and the rest is for saving (S). By merging the equations 1.2 and 1.3, another formulation is resulted as follows:

$$
\begin{aligned}
& C+S=Y d=Y-T x+T r \\
& C=Y d-S=Y-T x+T r-S
\end{aligned}
$$

The combination of the equations generates the formulations as follows:

$$
\begin{aligned}
& Y=Y-T x+T r-S+I+G+X-M \\
& S-I=(G-T x+T r)+X-M
\end{aligned}
$$

The equations indicate that the amount of saving and private sector investment surplus on the left is as big as the government budget deficit and the surplus of the balance of trade on the right.

The effect of regional expenditure on economic development can be explained that increasing Regional Expenditure will generate development projects. It will create job opportunities and boost economic development in the regions (Ribasauskiene, 2007). The multiplier effects of regional expenditure toward regional economic development can be determined by the amount of regional economy component budget for regional development projects. The more local components such as materials, supporting materials, and workforce being used, the larger the effects on the regional economic development (Ozekhome, 2017).

The concept of regional economic development is related to the availability of economic resources and other supporting factors, such as the economic policy of the regional government, bureaucratic system, infrastructure, etc. (Bhandari, 2013) The discussion of regional development theory is related to the dynamic of the economics theory development. (Hossain, 2001) The economics theory that discusses specifically the development of the regional economy is a regional science. The paradigm if the classical or neo-classical economy begins from the assumption of scarcity concept as a certainty faced by every individual on one side, and on the other side, each individual or group always tries to create a welfare economy (Lubik, 2016). The formulation of national product in the neoclassical is illustrated in an equation as follows:

$$
\mathrm{Y}=\mathrm{F}(\mathrm{K}, \mathrm{L})
$$

Descriptions:

$\mathrm{Y}=$ Output

$\mathrm{K}=$ Capital Stock

$\mathrm{L}=$ Workforce 
From the formulation 4.1, Cobb-Douglas's equation of production function can be formulated as follows:

$$
\begin{array}{r}
Y=L 1-\alpha K \alpha \\
0,,, \alpha 1
\end{array}
$$

The derivation of Cobb-Douglass's function equations becomes

$$
y=f(k)=k \alpha
$$

The net income of the increase of capital production factor $(k)$ can be formulated as follows:

$$
\frac{d k}{d t}=s f(k)-(n-\delta) k=s k^{\alpha}-(n+\delta) k
$$

Therefore, in the long-run, the capital stock per workforce amount is formulated as follows:

$$
s k^{\wedge} \alpha-(n+\delta) k^{\wedge} \alpha=0
$$

With the assumption that each individual has the freedom to choose, and the one who knows best is the individual, each individual with the principle of laize faire will conduct economic activities and make the best economy choices. (Aghevli \& Khan, 1978) From an economic perspective, economic problems occur because each individual group faces a scarcity problem. The economic power of each individual and group to achieve the goals is explained in an interaction between demand and supply in the marketplace, which will determine the balance illustrated in the curve as follows figure 3 .

The interaction between demand and supply will determine the balance that generates balance total and balance price. Classical and neoclassical theories have several weaknesses that ignore space as an essential variable to answer economic problems.

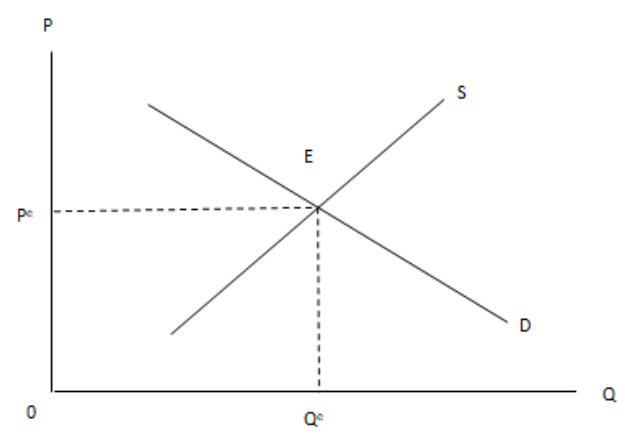

Figure 3 Demand, Supply, and Market Balance Source: Gregory Mankiw, 1998 


\section{Research Method}

This research used panel data analysis regression through secondary data. Data were obtained from Bank Indonesia (BI) and Statistics Indonesia (BPS). Some data also were collected from the research of Interregional Economy Development Study in Indonesia. Data consisted of Regional Gross Domestic Product (RGDP), Human Development Index, Domestic Investment, Foreign Investment, Regional Expenditure, Total Population, Exchange rate, and Length of Road. The data were accessed from the Statistics Indonesia website for seven years from 2010-2016, included 33 provinces in Indonesia, and the total number of data was 231 observations.

The method of analysis in this research was done using panel data analysis as a combination of time series and cross-section data. STATA statistical program package was employed to obtain the estimation of research variables in interest. Panel data analysis can be formulated in an economic model as follows:

$$
Y=\alpha+\beta_{1} X_{1} \text { it }+\beta_{2} X_{2} \text { it }+\ldots+\beta_{n} X_{n} \text { it }+\epsilon
$$

Each symbol is explained in detail as follows:

$$
\begin{aligned}
& \mathrm{Y}=\text { = Dependent variable } \\
& \alpha \quad=\text { Constants } \\
& \beta_{1}, \beta_{2}, \ldots . \beta_{n} \quad=\text { Regression coefficient } \\
& X_{1}, X_{2}, \ldots . X_{n}=\text { Independent variable } \\
& \epsilon \quad=\text { error term } \\
& \mathrm{t} \quad=\text { time } \\
& \mathrm{i}=\text { region }
\end{aligned}
$$

The panel data estimation can be executed using three approaches, namely, fixed effect, random effect, and common effect. The fixed effect assumes that differences between units of observation can be accommodated from their intercepts. The fixed effect estimation model is formulated as follows (Gujarati, 2002):

$$
Y_{i t}=\alpha+i \alpha_{i t}+X t_{i t} t \beta+\epsilon_{i t}
$$

The fixed effect approach can be solved with the least square dummy variable (LSDV). Meanwhile, the random effect model is a panel data analysis model, where errors are interrelated between time and individuals. Unlike the fixed effect in which the intercept differences are accommodated by dummy variables, in the random effect model, intercept differences are accommodated by error terms. The positive value of the random effect model approach is to eliminate the problem of heteroscedasticity. The formulation of the random effect model is as follows:

$$
Y=\alpha+\beta_{1} X_{i t}+\omega_{i t}
$$


Each symbol is explained in detail as follow:

$\mathrm{Y}=$ Dependent variable

$\alpha=$ Constants

$\beta=$ Regression Coefficient

$X=$ Independent variable

$\mathrm{i}=$ Individual/region/company

$\mathrm{t}=$ Time

$\epsilon=$ Error term

The common effect model is the simplest and least used panel data analysis model in research because it only combines time series and cross-section data without considering differences in time and units of observation. The estimation method in the common effect model can be done using the ordinary least square (OLS) method or least-squares technique. The formulation of the common effect model can be written as follows:

$$
Y=\alpha+\beta 1 X_{i t}+\epsilon
$$

Each symbol is explained in detail as follow:

$$
\begin{aligned}
& Y=\text { Dependent variable } \\
& \alpha=\text { Constants } \\
& \beta=\text { Regression Coefficient } \\
& X=\text { Independent variable } \\
& i=\text { Individual/region/company } \\
& t=\text { Time } \\
& \epsilon=\text { Error term }
\end{aligned}
$$

The classical assumption test of the panel data regression analysis model only included a multicollinearity test and a heteroscedasticity test. To obtain the appropriate data, the data on Regional Gross Domestic Product, total population, regional expenditures, domestic investment, and foreign investment were transformed into logarithm forms. Therefore, the numbers indicated the percentage of change of the variable. Data transformation from nominal data to logarithmic data would provide additional information on the percentage change in the independent variable toward the changes in the dependent variable.

\section{Result and Discussion}

Complete estimation results of panel data regression model with fixed effect approach, random effect, and common effect are shown in the following table 2. The table 2 presents the estimation results as indicated by regression coefficient values and probability values of common effect, fixed effect, and random effect model. After conducted the Chow test and Hausman test, then the estimations have selected the appropriate model, that was, the fixed-effect model. 
Yuliadi

Determinants of Regional Economic Growth in Indonesia

Table 2 The Estimation of Panel Data Regression Model

\begin{tabular}{lccc}
\hline \multicolumn{1}{c}{ Variable } & Common Effect & Fixed Effect & Random Effect \\
\hline Constants & 19,3920 & 19,3938 & 16,6417 \\
Human Development Index & 0,0004327 & $-0,0000102$ & $-0,0000188$ \\
& $(0,436)$ & $(0,904)$ & $(0,844)$ \\
\hline Log of Domestic Investment & 0,0671654 & 0,00221 & 0,002837 \\
& $(0,000)^{* * *}$ & $(0,387)$ & $(0,330)$ \\
\hline Log of Foreign Investment & 0,0611921 & 0,000825 & 0,0022427 \\
& $(0,000)^{* * *}$ & $(0,845)$ & $(0,639)$ \\
Regional Expenditure & 0,5697 & 0,078749 & 0,0947 \\
& $(0,000)^{* * *}$ & $\left(0,000^{* * * *}\right.$ & $(0,000)^{* * *}$ \\
Total Population & 0,5358 & 0,791853 & 0,9642 \\
& $(0,000)^{* * *}$ & $(0,000)^{* * *}$ & $(0,000)^{* * *}$ \\
Exchange Rate & $-0,000067$ & 0,0000324 & 0,0000269 \\
& $(0,000)^{* * *}$ & $(0,000)^{* * *}$ & $\left(0,000^{* * *}\right)$ \\
\hline Length of Road & $-0,0000057$ & $-0,0000041$ & $-0,0000039$ \\
Adjusted R-Squared & $\left(0,032^{* *}\right.$ & $(0,095)^{*}$ & $(0,129)$ \\
\hline
\end{tabular}

Sign $*, * *, * * *$ : indicate significant at $10 \%, 5 \%$, and $1 \%$

Looking at the estimation results on the fixed effect, it can be seen that there were independent variables that had a positive and significant effect on Regional GDP, such as regional expenditure, total population, and exchange rate. While, the rest of the independent variables, such as the Human Development Index (HDI), domestic investment, foreign Investment, and length of the road had no significant effect on Regional GDP. In addition, with the panel data regression approach of the fixed-effect model, it can be seen that the regression coefficient of the exchange rate was 0.0000324 , which means that the increase in the exchange rate by 1 point would increase the Regional GDP by $0.0000324 \%$. This phenomenon explains the increase in the exchange rate or the depreciation of the rupiah causes the value of Indonesian export commodities to become cheaper. Therefore, the demand for Indonesian goods in the world market will increase, respectively. Besides, Indonesia's exports will also increase, which ultimately increases the growth of Regional GDP. Conversely, the decline in the exchange rate, or other words, the appreciation of the rupiah against the US dollar, will cause Indonesian export commodities to become more expensive. Therefore, it reduces export revenues and the growth of Regional GDP.

The regression coefficient value of the population variable was 0.791853 , meaning that a population increased by $1 \%$ would increase the Regional GDP by $0.7918 \%$. This condition can be explained that the increase in population will affect the increasing demand for daily necessities so that consumption expenditures will increase. It finally leads to an increase in regional GDP. Likewise, the increase in the total population will increase labor productivity through competition at the workplace; as a consequence, it will increase the productivity of economic sectors, thus increasing the growth of Regional GDP. Barro and Lee (1994) also conducted research on the relationship between population and economic growth, but by using the phenomenon of migration concerning economic growth. Other studies on the relationship between population and economic growth have also been carried out by Mankiw, Romer, and Weil (1992), Levint and Renelt (1992). 
The regression coefficient value of the regional expenditure variable was 0.078749 , which means that an increase in regional expenditure of $1 \%$ would increase Regional GDP by $0.078749 \%$. This situation implies that regional expenditure is an important component in regional economic development. Through regional expenditure, it will create development projects to create jobs. Consequently, people's income will increase. Then, people's income will support public expenditure to increase as an attempt to improve the regional economy. Increasing regional expenditure will also support the use of regional economic products in the form of food, capital goods, handicraft products, small industrial products, and households to increase Regional Gross Domestic Product. In contrast, a decrease in regional expenditure will cause a decline in the development of projects in the region, leading to a decrease in job creation. As a result, the income and expenditure of the community will also decrease, then eventually reduce regional economic growth. Aschaurer (1989) has conducted research on the relationship between government spending and economic growth, which showed no significant relationship between government spending and economic growth. This research is also supported by Barro's (1991) research that explains the existence of the crowding-out phenomenon of tax policy to finance government spending.

The interesting thing from the research on interregional economic development in Indonesia is that there were no significant effects from the variables of domestic investment, foreign investment, and infrastructure (which was indicated by the length of road) towards regional economic growth. There are several reviews to see this phenomenon, among others, the value and amount of investment in the regions that are still relatively small. As a result, investment is not able to support regional economic growth. It is different from the investments in Java provinces, which are quite large; therefore, they affect to improve the regional economic growth, particularly in Java provinces. The lack of investment in other provinces, excluding Java provinces, has also become worse by the lack of infrastructure that supports economic activities, such as electricity, roads, bridges, ports, and airports. Although the government recently has been more proactive in building infrastructures, the development progress and infrastructure projects are concentrated in the Java region (Aghevli, 1976). Research on the relationship between investment and economic growth has also been carried out by Mankiw, et al. (1992). Ferreira (2000) conducted a study of the relationship between investment and economic growth in Brazil, and the results showed no significant relationship between investment and economic growth.

Likewise, the road infrastructure also had no significant effect on regional economic growth because the quality and length of roads in the regions were not enough to support regional economic growth. Moreover, roads become a vital facility for the distribution and transportation of goods between regions. It also supports regional economic activities and regional economic sectors in the regions. Limited length of road in the regions is caused by the lack of government budget to build road facilities and also the heavy natural terrain that becomes an obstacle for the construction of road facilities in the regions. However, one of the problems that often become an obstacle to road construction is the issue of land acquisition. Since this issue often creates disputes and conflicts with the local community. Vidyatama (2010) has also conducted research on the relationship between 
infrastructure and economic growth where transportation infrastructure had a positive and significant relationship to economic growth.

From these research findings, it was also found that the variable of the Human Development Index (HDI) had no significant effect on regional economic growth (RGDP). It is understood that the quality of Indonesian human resources as a whole has not shown adequate quality in the aspects of: education, health, skills, and experience. The total population of Indonesia is indeed large, but most of them live in Java island. Meanwhile, not many people are living outside Java island. The problem of uneven population distribution between regions is a matter of self-development in the regions. Likewise, the availability of educated labors and skilled labors are also mostly found in Java island but not outside Java island. Medical staff, doctors, agricultural scholars, civil engineers, professionals, entrepreneurs mostly come from Java region. This situation causes the Human Development Index to have no significant effect on regional economic growth in Indonesia since there is a disparity in terms of human capital between regions in Indonesia. Research on HDI with economic growth has also been carried out by Ferreira (2000) in Brazil, also conducted by Higgins, Levy, and Young (2003) in the USA. Garcia and Soelistianingsih (1998) have conducted research on HDI with economic growth and showed a positive and significant relationship.

\section{Conclusion}

In a nutshell, our findings can be summarized as follows: Regional economic growth in Indonesia is still driven by regional government spending through regional expenditure. Regional economic development in Indonesia is also driven by external factors through the variable exchange rate of the rupiah against the US dollar. Regional economic growth in Indonesia is driven by a large population. Regional economic growth in Indonesia was not influenced by domestic investment, foreign investment, and length of the road due to the uneven development of economic infrastructure between regions in Indonesia. Most of which are located in Java regions, which provides a more promising climate investment than other regions. Moreover, regional investments, both domestic and foreign investment, also infrastructure were not enough to support the growth of regional economic activities. Besides, regional economic development in Indonesia was not influenced by the variable of the Human Development Index (HDI). It implies the existence of a problem of the disparity of Indonesian human resources and human capital between regions. Since there is an uneven distribution of educated and trained human resources to support regional economic growth in Indonesia.

Based on those finding, policy recommendations on the study of interregional economic development in Indonesia were formulated as follows: (1) There is a need to increase and equalize the number and availability of quality human resources in all regions in Indonesia by increasing the human resources training programs and improving the educational system in Indonesia. There are some examples of the government's program to increase the educational system in Indonesia, such as providing scholarships and cash transfers to low-income families to increase the school enrolment in Indonesia. This program should 
be directed on target, mainly in some areas that are left behind or far from the center of development. Besides, the government should provide incentives for outstanding development actors, such as medical personnel, doctors, building engineers, agriculture instructors, teachers, and lecturers. This incentive aims to encourage them to support regional development. (2) Moreover, increased supervision of the quality of arterial road construction throughout the land by reducing corruption of development funds and integrated policies in handling land acquisition issues with the principle of win-win solutions and compensation for residents affected by road construction should also be taken into account. (3) There is a need for integrated policies in improving the investment climate through professional bureaucratic policies that are fast, efficient, and proactive towards the business world to increase political and security stability in the regions. The development of the investment climate is also related to the banking world, which can offer competitive and varied loans to meet the needs of business actors.

\section{References}

Aghevli, B. B. (1976). A Model of The Monetary Sector for Indonesia 1968-1973. Bulletin of Indonesian Economic Studies, 12(3), 50-60. https://doi.org/10.1080/00074917612331332979

Aghevli, B. B., \& Khan M. S. (1978). Government Deficits and the Inflationary Proces in Developing Countries. IMF Staff Papers, 25(3), 383-415. Retrieved from https://www.elibrary.imf.org/view/IMF024/15799-9781451972559/157999781451972559/15799-9781451972559 A001.xml? redirect=true

Aschaurer, D. A. (1989). Is Public Expenditure Productive. Journal of Monetary Policy, 23(2), 177-200. https://doi.org/10.1016/0304-3932(89)90047-0

Barro, R.J. \& Lee, J. W. (1994). Source of Economic Growth (with Comment from Nancy Stokey), Cornegie-Rochester Conference Series on Public Policy, 40, 1-46. https://doi.org/10.1016/0167-2231(94)90002-7

Barro, R.J. (1991). Economic Growth in A Cross Section of Countries. Quarterly Journal of Economics, 106(2), 407-443. https://doi.org/10.2307/2937943

Bhandari, P. B. (2013). Rural Livelihood Change? Household Capital, Community Resources and Livelihood Transition. Journal of Rural Studies, 32, 126-136. https://doi.org/10.1016/j.jrurstud.2013.05.001

Diallo, S. (2018). The Role of Human Capital in Guinea's Economic Growth an Empirical Analysis of The Educations Effect on Technological Progress over The Period 19802010. International Journal of Economic Development, 11(2), 155-197. Retrieved from https://spaef.org/article/1827/The-Role-of-Human-Capital-in-Guinea-s-EconomicGrowth-An-Empirical-Analysis-of-the-Education-Effect-On-Technological-Progressover-the-Period-1980-2010

Epaphra, M. (2018). An Econometric Analysis of The Determinants of Foreign Direct Investmen in Africa. International Journal of Economic Development, 11(2), 200-245. Retrieved from

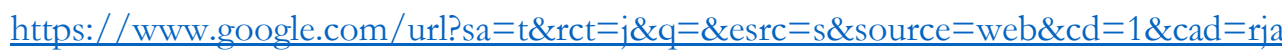
\&uact=8\&ved=2ahUKEwiLh6C1gbPpAhWK93MBHZyyBFIQFjAAegQIAxAB\&url $=$ https $\% 3 \mathrm{~A} \% 2 \mathrm{~F} \% 2 \mathrm{Fspaef} . \mathrm{org}^{2} \% 2 \mathrm{Ffile}$.php $\% 3 \mathrm{Fid} \% 3 \mathrm{D} 1828 \&$ usg-AOvVaw0DYG $9 \mathrm{~m}$ mFMhIf0HczJbyxV8

Ferreira, A. (2000). Convergence in Brazil Recent Trends and Long Run Prospects. Applied Economics, 32(4), 479-489. https://doi.org/10.1080/000368400322642 
Garcia, J., \& Soelistianingsih, L. (1998). Why Do Differnces in Provincial Income Persist in Indonesia. Bulletin of Indonesia Economics Studies, 34(1), 95-120. https://doi.org/10.1080/00074919812331337290

Gujarati, D. N. (2002). Basic econometrics, fifth edition. London: McGraw-Hill.

Higgins, M. J., D, levy., \& Young, A. (2006). Growth and Convergences A Cross the US Evidence from County Level Data, Review of Economics and Statistics. 1-17. https://doi.org/10.2139/ssrn.389680

Hossain, M.Z. (2001). Rural-Urban Migration in Bangladesh: A Micro-Level Study. Research Presentation in The Brazil IUSSP Conference, August, 20-24. Retrieved from https://www.researchgate.net/publication/228820071_RuralUrban Migration in Bangladesh A Micro-Level Study

Levine, R., \& Renelt, D. (1992). A Sensitivity Analysis of Cross-Country Growth Regressions. American Economics Review, 82(4), 942-963. Retrieved from https://www.jstor.org/stable/2117352?.seq $=1$

Lubik, T. A., \& Matthes, C. (2016). Indeterminacy and Learning: An Analysis of Monetary Policy in the Great Inflation. Journal of Monetary Economics, 82(1) 85-106. https://doi.org/10.1016/i.jmoneco.2016.07.006

Mankiw, N. G. (1998). Principles of economics. California: Dryden Press.

Mankiw, N. G., Romer, D., \& Weil, D. N. (1992). A Contribution to the Empirics of Economic Growth. The Quarterly Journal of Economics, 407-437. https://doi.org/10.3386/w3541

Ozekhome, H. O. (2017). Exchange Rate, Trade and Macroeconomic Stabilization Evidence from Nigeria. International Journal of Economic Development, 11(1), 29- 53. Retrieved from https:/ $/$ www.google.com/url? sa $=t \& r c t=j \& q=\& e s r c=s \& s o u r c e=w e b \& c d=1 \& c a d=r j a$ \&uact $=8 \& v e d=2$ ahUKEwjA0dHnhLPpAhWQIbcAHbXHCVAQFjAAegQIBBAB\&

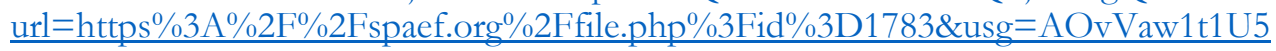
GSRUGTW1BPbe-71Bv

Pimentel, M. S., Harper, B., \& Martin, E. J. (2016). Addressing Poverty in Peru Degrowth Indigenous Local Farming and Technology Innovation. International Journal of Economic Development, 10(1), 104-147. Retrieved from https://spaef.org/article/1711/ADDRESSING-POVERTY-IN-PERUDEGROWTH-INDIGENOUS-LOCAL-FARMING-AND-TECHNOLOGYINNOVATION

Ribasauskiene, E. (2007). The Activities of Small and Mediumized Enterprises in Rural Areas Research Report, Lithuanian Institute of Agrarian Economic, 66. Retrieved from https://www.laei.lt/?lng=en

Todaro, M. P. (2000). Economics development in the third world. New York: The Longman Inc. Wilson, D. (2017). Economics Diversification and Development Among County Goverments in Appalachia. International Journal of Economics Development, 11(1), 54-77. Retrieved from https://spaef.org/ijed

Zhang, W. B. (2017). Spatial Agglomeration in a Monetary Multi-Regional Growth Model with Urban Residential Distribution. International Journal of Monetary Economics and Finance, 10(1), 68-95. https://doi.org/10.1504/ijmef.2017.10002263 